\title{
Koronavirüs (Covid-19) Salgınının Türkiye'deki Yemek Firmalarında Oluşturduğu Etkinin Belirlenmesi Üzerine Bir Araştırma
}

\author{
Mehmet Akif ŞEN ${ }^{1}$
}

\begin{abstract}
Özet
Koronavirüs (Covid-19) salgını Çin'de ortaya çıkan, kısa sürede tüm dünyaya yayılan 1 milyondan fazla kişiye bulaşmış bir hastalıktır. Bu çalışma hazır yemek üreten firmaların Covid19 salgınından ne derece etkilendiğini ve varsa almış oldukları tedbirleri belirlemeyi amaçlamıştır. Çalışmanın verileri Marmara Bölgesi'nde faaliyet gösteren yemek firmaları yetkililerinden elde edilmiştir. Çalışma sürecinde 23 firma yetkilisine ulaşılmış, yoğunluktan veya bilgi vermek istemeyenler düşüldükten sonra kalan 14 katılımcıdan elde edilen verilerle analizler yapılmıştır. Analizler sonucunda firmaların kapasite düşüş oranları tespit edilmiştir. Firmaların sektörde yer aldıkları sürenin fazla olmasının kapasite düşüşüne karşı bir önlem alamadıkları anlamına geldiği görülmüştür. Firmaların tamamının salgın dolayısıyla hizmetlerinde insan sağlığını koruyucu tedbirleri aldıkları tespit edilmiştir.
\end{abstract}

Anahtar Kelimeler: Covid-19, Koronavirüs, Catering, Kapasite, Kriz

\section{Study About a Coronavirus (Covid-19) Epidemic Effects on Catering Companies in Turkey}

\begin{abstract}
The coronavirus (Covid-19) epidemic is a disease that occurs in China and spread to more than 1 million people in a short time. This study aimed to determine the extent to which the catering companies are affected by the Covid-19 outbreak and the measures they have taken, if any. The data of the study were obtained from the authorities of the food companies operating in the Marmara Region. During the study process, 23 company officials were reached, and after the busy or those who did not want to give information were deducted, analyzes were made with the data obtained from the remaining 14 participants. As a result of the analysis, the capacity decrease rates of the firms were determined. It has been observed that the excessive period of time in which the companies take place in the sector means that they couldn't take any measures against the decrease in capacity. It has been determined that all firms take precautions to protect human health in their services due to the epidemic.
\end{abstract}

Keywords: Covid-19, Coronavirüs, Catering, Capacity, Crisis

\footnotetext{
${ }^{1}$ Dr. Öğr. Üyesi, Gastronomi ve Mutfak Sanatları Bölümü, Giresun Üniversitesi, Giresun

İlgili yazar/Corresponding author: Mehmet Akif Șen e-posta: mehmetakifsenn@gmail.com ORCID No: 0000-0002-2987-8074
}

Bu makaleye atıf yapmak için- To cite this article Şen, M. A. (2020). Koronavirüs (Covid-19) Salgınının Türkiye'de ki Yemek Firmalarında Oluşturduğu Etkinin Belirlenmesi Üzerine Bir Araștırma. Afet ve Risk Dergisi, 3(1), 89-100. 


\section{GíRiş}

Toplu yemek firmalarının hizmet verdiği insanlar ev dışında toplu bir şekilde bir arada bulunan ve yemek hizmeti alan okul, hastane, sanayi kuruluşları gibi işletmelerin çalışanlarıdır. Türkiye'de toplu yemek firmalarının ürettiği toplam yemek sayısına ait 2019 veya 2020 yılının güncel verileri bulunmamakla birlikte en güncel veri 2016 yılı sonunda açıklanmıș olan günlük 22 milyon porsiyon yemek șeklindedir (Șen ve Şimșek, 2020). Toplu yemek firmalarının günlük yemek üretim kapasitesi hafta sonu tatili, resmi ve dini bayramlarda yapılan tatiller, okulların yarıyıl ve yaz dönemi tatilleri, mücbir sebepler ( kar yağıșı ile insanların ișyerine gidememesi, işyerinde meydana gelen yangın, afet gibi sebepler) ve devletin resmi organları tarafından alınan önlemler sonucu değișmektedir.

Çin'in Wuhan kentinde 12 Aralık 2019 tarihinde ortaya çıkan ve o tarihten bu yana dünyada hızlı bir şekilde yayılış gösteren yeni tip Coronavirüs (COVİD-19) insanlık için büyük bir tehdit oluşturmaktadır(URL 1). Tüm yaş gruplarındaki insanları enfekte eden bu virüs özellikle yaşı 65 üzeri insanları daha fazla etkilemektedir (Ovalı, 2020). Türkiye'de ilk Covid-19 vakası 11 Mart 2020 tarihinde tespit edilmiş olup ilk ölüm vakası ise 18 Mart 2020 olarak kayıt altına alınmıştır (URL 1). Vakaların ve ölümlerin artmasının ardından Türkiye'de insanların birbiriyle olan temasını azaltmak amacıyla önlemler alınmaktadır. Alınan bu önlemler sonucu Türkiye'de halkın sokağa çıkma oranı azalma göstermektedir. Bunun sonucu olarak çalışanların \%45'i işyerlerine devam etmektedir (URL 2). Bu durumun işyerlerine toplu yemek hizmeti sağlayan yemek firmalarına da yansımış olduğu düşünülmektedir. Bu amaçla, Türkiye'de işyerlerine yemek hizmeti sağlayan yemek firmalarının bu durumdan ne şekilde etkilendiklerini ortaya çıkartmak amaçlanmıştır. Çalışma sonucunda; ortaya çıkacak olan kapasite düşüş oranları, bu düşüş oranına göre yemek firmalarının almış oldukları aksiyonlar, salgın gibi gelecekte nasıl bir durumla sonuçlanacağı belli olmayan bir vakada sergilenebilecek davranış biçimlerini ortaya koyarak hem bu alana yönelik çalışma yapacak araştırmacılara hem de sektör yetkililerine sağlıklı ve bilimsel dayanağı olan öneriler sunulabilecektir.

\section{LİTERATÜR TARAMASI}

Coronavirus'lar, dünya üzerinde şu ana kadar soğuk algınlığı, Orta Doğu Solunum Sendromu (MERS) ve Ağır Akut Solunum Sendromuna (SARS) sebep olan bir virüs ailesidir. 12 Şubat 2020 tarihinde COVID-19 olarak adlandırılmaya başlayan bu virüs zoonotik yani hayvanlardan insanlara bulaşarak hastalık yapabilmektedir (Acar, 2020; Akpınar ve Üstün, 2020). İnsanlarda hastalık yapan bu virüslerin sığır, deve ve yarasa gibi hayvanlardan geçtiği tahmin edilmektedir. Öyle ki SARS'ın 2002 yllında Çin'de yarasalardan, MERS'in ise 2012 yılında Suudi Arabistan'da develerden insanlara geçtiği raporlanmaktadır. 2019 yılının Aralık ayında ortaya çıkan COVID19 'un ise ilk kaynağının deniz hayvanları olduğu fakat bulaşmanın insandan insana damlacık yoluyla veya temas yoluyla gerçekleştiği belirtilmektedir (Acar, 2020; Ovalı, 2020).

COVID-19 olduğuna dair bulgular taşıyan insanların eğer hekim veya yetkili bir kuruluş tarafından aksi belirtilmemişse kendini bütün insanlardan 14 gün boyunca izole etmesi gerekmektedir. İzolasyon süresince bulunulan ortamın camları açılarak havalandırılması, kişiye özel veya tek kullanımlık kağıt havlu, kişisel veya tek kullanımlık yemek kapları kullanılması tavsiye edilmektedir (Akpınar ve Üstün, 2020).

COVID-19 enfeksiyonu, toplum içinde salgına, hastalıklara ve sonucunda ölümlere yol açmakta aynı zamanda da halklara ve devletlere sosyoekonomik anlamda zarar vermektedir. Dünya üzerinde virüsün bulunduğu tüm ülkelerde salgının önlenmesi, geriletilmesi ve ortadan tamamen kaldırılması amacıyla alınması gereken bütün bireysel ve toplumsal önlemler, 
devletlerin yasa ve yönetmeliklerinde yapacakları değişikliklerle ve sahada etkin rol oynamasıyla başarıya ulaşacaktır (Karcıoğlu, 2020).

Dünya Sağlık Örgütü'nün yayınlanmış olduğu günlük rapora göre 09.04.2020 tarihinde Dünya üzerinde 1.353.361 kişiye COVID-19 bulaşmıștır. Bu kişilerden 79.235 kişi ise hayatını kaybetmiştir (URL 3). Türkiye'de aynı tarihte hastalık bulaşan sayısı 38.226, toplam vefat eden sayısı 812, toplam iyileşen ve hastaneden taburcu olan hasta sayısı ise 1.846 kişidir (URL 4). WHO tarafından yayınlanmış olan aynı raporda insanlar arasındaki temasın kesilmesinin önemi bir kez daha dile getirilmekle birlikte farklı sektörlerin katılımıyla durumun sosyal ve ekonomik açıdan değerlendirilmesi gerektiği önerilmektedir (URL 3).

Türkiye'de salgının önüne geçmek amacıyla alınan tedbirler şu şekildedir;

- 13.03.2020 tarihinden itibaren Dünya üzerinde salgının arttığı ülkelerden sonrasında ise tüm ülkelerden kara, hava ve deniz yoluyla Türkiye'ye yolcu taşımacılığı sonlandırılmıştır.

- Tüm resmi ve özel ilköğretim okulları ve liseler ile üniversiteler tatil edilerek salgının önüne geçilmesi amaçlanmıştır.

- Tüm spor müsabakaları ilk etapta seyircisiz oynanmış daha sonra süresiz ertelenmiștir.

- İlk etapta 65 yaş üzeri daha sonra da 20 yaş altı vatandaşlar için sokağa çıkma yasağı getirilmiştir. Ölümlerin daha çok yaşlı insanlarda görülmesi, yaşlı hastalara da çocukların sokaktaki temastan virüs kaparak taşıması ihtimaline karşı bu yasak uygulanmaktadır.

- Devletin resmi kurumlarından sürekli "evde kal Türkiye" uyarıları yapılmaktadır.

- Şehirlerarası insan hareketliliğini engellemek amacıyla şehirlerarası yolculuk uçak ve otobüslerle yasaklanmıştır. Özel araçlarla geçişler izne bağlı olmakla birlikte tüm büyükşehirlerde ve Zonguldak ilinde özel araç geçişi dahi olmamaktadır.

- Maske takmanın salgını önlediği açıklanarak ülke genelinde marketlerde maske takma zorunluluğu uygulanmaya başlanmıştır (URL 5).

COVID-19 çok küçük boyutlu bir virüs olduğundan öksürme, hapşırma, konuşma gibi etmenlerle karşı tarafta bulunan insanlara bulaşmaktadır. Bu virüsü taşıyan insanların ellerini ağızlarına götürmeleri sonucu herhangi bir yere veya herhangi bir kişiye elleriyle temas etmeleri durumunda ellerinden veya temas ettikleri yere temastan dolayı başka birine bulaşma olmaktadır. Virüs 2 metre uzaklıktan karşıdaki insana bulaşabilmekte ve bir kişi 2,6 kişiye bu virüsü enfekte edebilmektedir (Karcığglu, 2020; Ovalı, 2020).

Toplu yemek firmalarının hizmet sunma şekli; yemeği pişirerek, yemek hizmeti alan kurum çalışanları tarafından yiyen müşterilere dağıtılması amacıyla yollamak veya yemeği pişirip kendisi tüketicilere dağıtmaktır (Şen ve Şimşek, 2020). Yemek hizmetinde menü çorba, ana yemek, yardımcı yemek, tatlı, salata, meyve, yoğurt döngüsü şeklinde gerçekleşmektedir. Bu hizmeti veren yemek firmaları; sundukları yemekte yeterli ve dengeli beslenmeyi sağlamalı bunun yanında gida güvenliği önlemlerinden taviz vermemeleri gerekmektedir. Aksi takdirde hastalık ve sonu ölümle bitecek gıda zehirlenmelerine sebebiyet verilebilmektedir. Bunun için alınması gereken tedbirlerden bir tanesi de personel hijyenidir. Personelin ellerinden, pişmiş gıdaya temas ile hastalıklı veya taşıyıcı olan personelin çalıștırılması sonucu ise ağız ve solunum yolu ile yemek dağıtımı esnasında yemeklere veya hizmet sunulan kişilere virüs veya mikroorganizma geçişi olmaktadır. Bunu önlemenin yolu kişisel hijyen koruyucu ekipmanlar kullanmak ve bireysel hijyene dikkat etmektir. Yemek sektöründe, tek kullanımlık eldiven ve tek kullanımlık maske kişisel hijyen ekipmanları olarak kullanılmaktadır. Çiğ gıdadan pişmiş gıdaya eller ile kontaminasyon olabilmektedir. Eğer çıplak elle tutulması gereken bir gıda var ise mutlaka ellerin uygun bir yıkama talimatı ile yıkanması ve uygun dezenfektanlar ile dezenfekte 
Koronavirüs (Covid-19) Salgınının Türkiye'deki Yemek Firmalarında Oluşturduğu Etkinin Belirlenmesi Üzerine Bir Araştırma

edilmesi gerekmektedir. Çiğ gıdayı işlemek için kullanılan eldivenin pişmiş gıdayı işlerken değiştirilmesi gerekmektedir (Kaya ve İlhan, 2018; Şen, 2017).

Ağız boşluğu, burun ve boğazda insanlar için hastalık yapıcı virüs ve bakteriler bulunmaktadır. Bu mikroorganizmalar bulundukları kişide hastalık göstermeyip diğer insanları hastalık yapıcı özelliğe sahip olabilmektedir. Bu tarz bulaşıcılık özellikte olanların tedavilerinin yapılması ve işletmede çalıştırılmaması gereklidir. Eğer çalışacakları bir durum söz konusu ise ağız ve burunu içine alarak kapatacak maske kullanılması gerekmektedir (Demirel, 2009; Kaya ve İlhan, 2018; Şen, 2017).

Yemek hizmeti; taşıma yemek hizmeti, yerinde üretim yemek hizmeti, yerinde üretim destekli taşıma yemek hizmeti ve paket yemek hizmeti olarak sınıflandırılmaktadır (Sucu ve ark, 2020). Yemek firmaları bir otomotiv, kırtasiye, televizyon gibi ürün satışı yapan firmalardan biraz daha farklı değerlendirilmesi gerekmektedir. Henüz üretimi yapılmamış bir ürünün satışı için müşteriyle sözleşme imzalanmaktadır. Yemeği üretmek ile iş sonlanmamaktadır. Yemek firmaları yemeğin üretiminin ardından müșteriye ulaştırılması, tabaklarda sunumu daha sonra da tabakların yıkanması gibi hizmetlerin tamamını yerine getirmektedir. Bundan ötürü müşteriyle karşılıklı bir güven ilişkisi olması gerekmektedir. Müşteri veya müşterinin sektörü ile alakalı geçmişte yaşanan problemleri araştırarak hizmet sözleşmesi yaptığı süre içerisinde ne gibi problemlerin olabileceğini önceden görmek, analiz etmek ve kriz ortamlarında önceden önlem alması gerekmektedir. Yemek firmaları geleceği planlamak durumundadır. Özellikle yemek fiyatı oluştururken sabit giderlerin, müşteri yemekhanesinde hizmet verecek personelin, ödeme vadelerinin, günlük tüketilecek yemek adetinin, yemeğin hammadde gramaj bilgilerinin, genel üretim giderlerinin, temizlik giderlerinin ve tüm maliyet kalemlerinin doğru hesaplanması çok önemlidir (Gürsoy, 1997).

Çalışmamızda Türkiye'nin çeşitli şehirlerinde faaliyet gösteren yemek firmalarının Covid-19 salgını sebebiyle alınan önlemlerden ne şekilde etkilendiğine yönelik nitel bir araştırma yapılmıştır. Araştırmamızda firma yetkilileriyle görüşülerek üretim kapasitelerinin ne oranda değiştiği, aldıkları önlemlerin neler olduğu, bu süreçte yaşadıkları olumsuzluklar hakkında kendilerine sorular sorulmuştur. Çalışma, Covid-19 sebebiyle ortaya çıkan ölüm vakalarındaki artışa paralel Türkiye'de ki alınan önlemlerin yemek sektörünü ne yönde etkileyeceği bakımından önemlidir.

\section{YÖNTEM}

Toplu yemek sektörünün COVİD-19 salgınından etkilendiği düşünülmektedir. Yemek firmalarının hazır yemek üretimi ve servisi yapmalarından dolayı piyasaya güvenli gıda arz etme sorumluluğu bulunmaktadır. Özellikle insan etkisiyle yayılan bir hastalık yemek firmalarını sıkıntıya düşürebilecektir. Salgından ötürü faaliyetlerine devam edemeyen kurum ve kuruluşlara sunulamayan yemek hizmetinden ötürü sektörün yaşayacağı problemlerde bulunmaktadır. Bu konuları derinlemesine anlamak ve sürecin nasıl işlediğine dair bulguları elde etmek amacıyla nitel bir araştırma yapılmıştır. Gözlem, görüşme ve doküman analizi gibi veri toplama tekniklerinin kullanıldığı, olayların doğal ortamda izlendiği ve araştırıldığı yöntem nitel araștırma yöntemidir. Nitel araştırmada; çevreyle, süreçle ve algılarla ilgili olmak üzere 3 tür veri toplanmaktadır. Araştırmanın tasarlanması ve gerçekleşmesinde araştırmaya büyük esneklik sağlayan bu yöntem araştırmacıya araştırmanın her aşamasında yeni yöntem ve yaklaşımlar geliștirme ve araştırmanın kurgusunu değiştirme fırsatı sunmaktadır (Yıldırım ve Şimşek, 2008; Neuman, 2012).

$\mathrm{Bu}$ araștırmayı yapmak amacıyla Türkiye'nin özellikle sanayisinin yoğun olduğu Marmara Bölgesi'ndeki yemek firmalarının yöneticileriyle telefonda irtibat kurulmuştur. Kişi iletişim 
bilgileri Gıda Mühendisleri Odası yetkililerinden elde edilmiștir. $\mathrm{Bu}$ amaçla 23 adet yemek firması yöneticisi aranarak uygun oldukları bir zamanda telefonda 20-30 dakika arası bir görüşme yapılması ve bu görüşmelerin, telefonun ses kaydedici özelliği ile kayıt altına alınması gerektiği kendilerine bildirilmiştir. Fakat yöneticilerden 9 tanesi bu sıralar çok sıkıntılı bir süreç geçirdiklerini ve bu bilgileri paylaşmak istemediklerini söylemişlerdir. Dolayısıyla geriye kalan 14 tane yönetici ile görüşme yapılarak konu ile ilgili derinlemesine ve çok yönlü veriler elde edilebilmiştir.

Araştırmada yöneticilere ilk etapta firmaların tesislerinin bulunduğu lokasyon, hizmet verdikleri lokasyon, kaç yıldır sektörde bulundukları, salgın öncesi ve salgın sonrası günlük yemek üretim kapasiteleri sorulmuştur. Verilen bilgilere göre görüşme esnasında firmaların kapasite değişim oranları hesaplanmıştır. Bu hesaplama sonucu kapasite düşüşü sonucunda firmaların almış oldukları önlemler ayrıca devam eden yemek hizmetinde ise dengeli beslenme ve güvenli gıda üretimi amacıyla yapılan çalışmalar öğrenilmiştir. Katılımcıların müsaadesiyle alınan ses kayıtları daha sonradan çözümlenmiştir. Görüşmelerden elde edilen veriler betimsel analiz tekniği ile analiz edilmiștir.

\section{BULGULAR}

Çalışmaya katılan yemek firmaları, isimlerinin yayınlanmasını kabul etmemişlerdir. Bundan ötürü "Yemek Firması" olarak adlandırıldıktan sonra YF olarak kısaltılmış ve yanlarına sayılar (YF 1, YF 2, , YF 14) yazılarak kodlandırılmıştır. Yemek firmalarının Tablo 1'den de görüleceği üzere 4 tanesi Kocaeli, 4 tanesi Bursa, 5 tanesi İstanbul ve 1 tanesi de Tekirdağ illerinde faaliyet göstermektedir. Firmaların yemek hizmeti sundukları lokasyonlar fabrikalarının kurulu olduğu bölgeyi merkez alarak etraflarında bulunan il veya ilçeler olarak ortaya çıkmaktadır. Buna göre çalışmaya katılan firmalar tarafından hizmet verilen lokasyonlar Bursa ilinin tamamı, Kocaeli ilinin tamamı, İstanbul ilinin tamamı ve Çorlu civarıdır.

Tablo 1. Yemek firmalarının üretim tesislerinin bulunduğu ve hizmet verdiği lokasyon ile faaliyet süreleri

\begin{tabular}{|l|l|l|l|c|}
\hline Yemek Firması Adı & Kodu & Bulunduğu Lokasyon & Hizmet Verilen Lokasyon & $\begin{array}{c}\text { Faaliyet } \\
\text { Süresi } \\
\text { (Yıl) }\end{array}$ \\
\hline Yemek Firması 1 & YF 1 & Gebze / KOCAELI & Sakarya - Kocaeli - İstanbul & 17 \\
\hline Yemek Firması 2 & YF 2 & Gebze / KOCAELI & Gebze - İstanbul & 3 \\
\hline Yemek Firması 3 & YF 3 & İzmit / KOCAELI & İzmit & 6 \\
\hline Yemek Firması 4 & YF 4 & Kartal / İSTANBUL & İstanbul - Dilovası & 26 \\
\hline Yemek Firması 5 & YF 5 & Nilüfer / BURSA & Bursa ve İlçeleri & 8 \\
\hline Yemek Firması 6 & YF 6 & Osmangazi /BURSA & Bursa ve İlçeleri & 14 \\
\hline Yemek Firması 7 & YF 7 & Nilüfer / BURSA & Bursa ve İlçeleri & 15 \\
\hline Yemek Firması 8 & YF 8 & Küçükçekmece /ISTANBUL & Küçükçekmece & 4 \\
\hline Yemek Firması 9 & YF 9 & Büyükçekmece / İSTANBUL & Büyükçekmece \\
\hline Yemek Firması 10 & YF 10 & Gebze / KOCAELI & Gebze - Tuzla & 4 \\
\hline Yemek Firması 11 & YF 11 & Çorlu / TEKIRDAĞ & Çorlu ve çevresi & 7 \\
\hline Yemek Firması 12 & YF 12 & Şişli / İSTANBUL & İstanbul Avrupa Yakası & 11 \\
\hline Yemek Firması 13 & YF 13 & Osmangazi / BURSA & Bursa ve İlçeleri & 44 \\
\hline Yemek Firması 14 & YF 14 & Sarıyer / İSTANBUL & İstanbul Avrupa Yakası & 8 \\
\hline
\end{tabular}


Koronavirüs (Covid-19) Salgınının Türkiye'deki Yemek Firmalarında Oluşturduğu Etkinin Belirlenmesi Üzerine Bir Araştırma

Yemek firmalarının faaliyet sürelerini öğrenmek amacıyla sorulan soruya ilişkin veriler Tablo 1 'de görülmektedir. Bu tabloya göre çalıșmaya katılan firmaların faaliyet süresi 3 ile 44 yıl arasında değișmektedir.

Salgının, yemek firmalarında meydana getirdiği kapasite düşüklüğü çalışmamız açısından önemlidir. Tablo 2 incelendiğinde firmalardaki kapasite kayıp oranının \% 26.40 ile \% 93.79 arasında değiştiği görülmektedir. Çalışma yapılan firmaların toplam ürettiği yemek sayısına göre yaşanan kayıp \% 62.43'tür. \% 26.95 ile YF 3 firması, kapasitesini daha az oranda kaybetmesini hizmet sunduğu kuruluş sayısının fazlalığına bağlamaktadır. Bu firma 43 adet kuruluşa yemek hizmeti vermektedir. Hizmet sunduğu kuruluşların günlük sayıları 6 ile 115 kiși aralığındadır. Bu durum yemek hizmeti alamama riskini dağıtmak anlamında önemli görülmektedir. En fazla kapasite kaybının \%93,79 ile meydana geldiği YF 12 firmasının hizmet verdiği bölge İstanbul Avrupa yakasıdır. Firma yetkilisi, müşterilerinin daha çok plaza çalışanları olduklarını belirtmiştir. Plaza çalışanları olması sebebiyle evde çalışma sistemine geçen kuruluş sayısı oldukça fazladır. Çağrı merkezi veya firmaların genel müdürlükleri olması sonucu, bir hizmetin görülebilmesi amacıyla işyeri ortamını bu kuruluşlar çalışanların evlerine taşımışlardır. $\mathrm{Bu}$ durum yemek firmasının kapasitesinin neredeyse tamamını kaybetmesine sebebiyet vermektedir.

YF 1, YF 4, YF 10 ve YF 13 firmalarının yetkilileri okul müşterilerinin bulunduğunu belirtmektedir. Okullarda hizmet verdikleri öğrenci sayılarını yaklaşık olarak sırasıyla 2800, 1300, 800 ve 3700 kişi olarak belirtmektedirler. Sayıların yüzün katları şeklinde olmaları yetkililerin sayıları ortalama olarak vermelerinden kaynaklanmaktadır. Bu durumda okul kaynaklı kayıplar bu yemek firmalarında sırasıyla \%10.83, \%7.03, \% 16.43 ve \% 8.15 olmaktadır.

Tablo 2 . Yemek firmalarının salgın öncesi ve salgın sonrası yemek üretim kapasitesi ve değișim oranı

\begin{tabular}{|l|r|r|r|}
\hline $\begin{array}{l}\text { Firma } \\
\text { Kodu }\end{array}$ & $\begin{array}{c}\text { Salgın Öncesi } \\
\text { Kapasite(Kişi/Gün) }\end{array}$ & $\begin{array}{c}\text { Salgın Sonrası } \\
\text { Kapasite(Kişi/Gün) }\end{array}$ & $\begin{array}{c}\text { Kaybedilen } \\
\text { Kapasite ( \%) }\end{array}$ \\
\hline$Y F$ 1 & 25.850 & 8.960 & 65.34 \\
\hline$Y F$ 2 & 8.140 & 1.460 & 82.06 \\
\hline$Y F$ 3 & 8.750 & 6.440 & 26.40 \\
\hline$Y F$ 4 & 18.500 & 4.300 & 76.76 \\
\hline$Y F 5$ & 7.540 & 2.460 & 67.37 \\
\hline$Y F$ 6 & 16.180 & 5.970 & 63.10 \\
\hline$Y F$ 7 & 21.960 & 6.650 & 69.72 \\
\hline$Y F$ 8 & 1.700 & 875 & 48.53 \\
\hline$Y F$ 9 & 2.320 & 1.030 & 55.60 \\
\hline$Y F$ 10 & 4.870 & 2.080 & 57.29 \\
\hline$Y F 11$ & 5.640 & 4.120 & 26.95 \\
\hline$Y F 12$ & 4.350 & 270 & 93.79 \\
\hline$Y F 13$ & 45.380 & 20.850 & 54.05 \\
\hline$Y F 14$ & 6560 & 1320 & 79.88 \\
\hline Toplam & $\mathbf{1 7 7 . 7 4 0}$ & $\mathbf{6 6 . 7 8 5}$ & $\mathbf{6 2 . 4 3}$ \\
\hline
\end{tabular}


Yetkililer, firmalarının kapasite düşüş sebeplerini şu şekilde açıklamaktadırlar;

- Yemek sayısı 5 kişiden 120 kişiye değișen aralıkta çok fazla müşterimiz bulunmaktadır. Bu kuruluşların birçoğu vardiya sistemi ile çalışmamaktadır. Vardiya sistemi bulunanlarında belli bir kısmında günde 2 vardiya çalışılmaktadır. Bu müşterilerimiz çalışanlarının belli kısmını çalıştırmayarak izne yollamıştır. Geriye kalan personelle de vardiya sayıları 3'e tamamlayarak çalışmalarına devam etmektedir. 3 vardiyaya dönülmesi aynı çalışma alanında daha az personelin çalıștığı anlamı taşımaktadır (YF 3, YF 8, YF 11) .

- Bant usulü çalışan müşterilerimiz bulunmaktadır. Bunlar zaten 3 vardiya çalıştıkları için yeni bir vardiya ayarlamaları mümkün olmadı. Bu tarz firmalarımız çalışma esnasında sosyal mesafeyi gözeterek personelin arasındaki mesafeyi genişlettiler. Bu nedenden dolayı çalışan sayımız azaldı. Ayrıca firmaların ofiste bulunan çalışanların büyük kısmına evden çalışması gerektiği bildirilerek evlerine gönderildi. Bundan dolayı sayılarımızda düşüş oldu (YF 2, YF 5, YF 7, YF 13).

- Bazı müşterilerimiz tesislerindeki faaliyeti tamamıyla durdurarak yıllık rutin yapılması gereken bakım, onarım ve temizlik işlerini yerine getirmektedirler (YF 1, YF 2, YF 3, YF 4, YF 5, YF 6, YF 7, YF 8, YF 9, YF 10, YF 11, YF 12, YF 13, YF 14).

Kapasite kaybına yemek firmalarının aldığı yalnızca bir önlem bulunmaktadır. Alındığı bildirilen bu önlem personele yıllık izinlerini kullandırmaktır. Firmanın yemek üretimi yapmadığı dönemde boşta kalan personel için kazanılmış olan yıllık izinlerin tamamı firmalar tarafından kullandırılacaktır. Yıllık izinlerin bitmesinin ardından ücretsiz izin kullandırılmaktadır. Fakat salgının uzun sürmesi durumunda katılımcılar işten personel çıkartmayı da düşünebileceklerini belirmektedir.

Çalışmamıza katılan firmaların hangi sektörlere hizmet verdiğine dair sorduğumuz soru sonucunda en çok cevap verilen otomotiv, tekstil, gıda, inşaat şantiyesi ve kimya sektörleri tabloya koyulmuştur. Eğitim cevabını veren firma sayısının az olmasına rağmen tabloya dahil edilmesinin amacı okulların devlet tarafından tatil edilmiş olmasıdır. Ofis, genel müdürlük, çağrı merkezi gibi sektörler diğer sütunu altında değerlendirilmiştir.

Tablo 3 incelendiğinde 14 firmanın 9 tanesi otomotiv sektörüne, 14 tanesi tekstil sektörüne, 11 tanesi gida sektörüne, 7 tanesi inşaat şantiyelerine, 14 tanesi kimya sektörüne, 4 tanesi eğitim sektörüne ve 14 tanesi diğer diye gruplandırdığımız (ofis, genel müdürlük, çağrı merkezi) sektörlere hizmet vermektedir.

Tablo 3 yemek firması özelinde incelendiğinde ise YF 12'nin 3 sektöre, YF 8 ve YF 14'ün 4 sektöre, YF 2, YF 3, YF 6, YF 7 ve YF 9 firmalarının 5 sektöre, YF 1, YF 4, YF 5, YF 11 ve YF 13'ün 6 sektöre ve son olarak ise YF 10'un tüm sektörlere hizmet verdiği görülmektedir. Bu sonuçlar kapasite düşüş tablosuyla karşılaştırıldığında yemek sayısındaki düşüşün bütün sektörlere hizmet veren yemek firmalarında meydana geldiği ortaya çıkmaktadır.

Firmaların tamamı salgından önceki yemek hizmetini tanımlarken menülerinde; çorba, ana yemek, yardımcı yemek, tatlı veya meyve, salata veya yoğurt/ayran sunduklarını belirtmişlerdir. Toplu olarak kuruluşlara getirilen yemekler burada yemek yiyenlere kepçe gibi mutfak ekipmanlarıyla dağıtılmaktadır. Yemek yenen ekipman ya porselen tabak ya da tabldot tabaktır. Salata ve yoğurt müşteri tarafından porsiyonlamakta, meyve kendi eliyle almaktadır. Tuz, baharat, ketçap, mayonez, su ve ekmek masada ortak bir eşyanın içinde bulunmakta isteyen kendi ihtiyacı kadar almaktadır. 
Koronavirüs (Covid-19) Salgınının Türkiye'deki Yemek Firmalarında Oluşturduğu Etkinin Belirlenmesi Üzerine Bir Araștırma

Tablo 4'ü incelediğimizde yemek firmalarının tamamının hizmetlerinde ciddi değișikliklerin meydana geldiği gözlenmektedir. En temel değişikliğin yemek yenen ekipmanlarda olduğu göze çarpmaktadır. Salgın öncesi tabak, tabldot, çatal, kaşık gibi yıkanabilir ve tekrar kullanılabilir ekipman kullanan hizmet alan kuruluşlar salgın sonrası tek kullanımlık ekipmanlar kullanmaktadır. Müșteriden gelen talep veya yemek firmasının teklifiyle yapılan bu uygulamanın amacı virüsün yayılımını engellemektir. Salata, tatlı ve meyveler artık yemek üretim tesisinde kişiye özel paketlenmekte ve o şekilde hizmet alanlara sunulmaktadır. Sürahilerden doldurulan su yerine ambalajlı su, dilimlenmiş ekmek yerine ambalajlı ekmek, şişeden dökülerek kullanılan ketçap ve mayonez yerine tek kullanımlık saşe ambalaj, porsiyonlanarak kullanılan yoğurt yerine ise ambalajlı yoğurt ve ayran kullanılmaktadır. Yemek firmalarının tamamında olmak üzere hizmet alan kuruluşların özellikle bir ögünde yemek yiyen sayısının 50'nin altına düşmüş olanlarında çorba, ana yemek, yardımcı yemek, tatlı, meyve gibi menülerin yerine sandviç ekmek içerisine hazırlanmış yemekler veya tamamı ambalajlı olmak kaydıyla kahvaltılıklara geçiş yapılmaktadır.

Katılımcılar kendi çalışanları ve işletmeleri için aldıkları önlemlere örnek olarak personel servislerinin sayısı arttırmak, hijyen eğitimleri düzenlemek, işyerlerinde sosyal mesafeyi koruyarak çalışmak, temizlik ve dezenfeksiyon sıklığını arttırmayı vermektedirler.

Tablo 3 . Yemek firmalarının hizmet verdikleri sektörler

\begin{tabular}{|c|c|c|c|c|c|c|c|}
\hline $\begin{array}{l}\text { Firma } \\
\text { Kodu }\end{array}$ & Otomotiv & Tekstil & Gida & Şantiye & Kimya & Eğitim & $\begin{array}{l}\text { Diğer (Ofis, gn } \\
\text { md, çağrı mrk }\end{array}$ \\
\hline$Y F 1$ & + & + & + & - & + & + & + \\
\hline$Y F 2$ & + & + & - & + & + & - & + \\
\hline$Y F 3$ & - & + & + & + & + & - & + \\
\hline$Y F 4$ & + & + & + & - & + & + & + \\
\hline$Y F 5$ & + & + & + & + & + & - & + \\
\hline$Y F 6$ & + & + & + & - & + & - & + \\
\hline$Y F 7$ & + & + & + & - & + & - & + \\
\hline$Y F 8$ & - & + & - & + & + & - & + \\
\hline$Y F 9$ & - & + & + & + & + & - & + \\
\hline$Y F 10$ & + & + & + & + & + & + & + \\
\hline$Y F 11$ & + & + & + & + & + & - & + \\
\hline$Y F 12$ & - & + & - & - & + & - & + \\
\hline$Y F 13$ & + & + & + & - & + & + & + \\
\hline$Y F 14$ & - & + & + & - & + & - & + \\
\hline
\end{tabular}


Tablo 4 . Yemek firmalarının salgın sonrası hizmet değişiklikleri

\begin{tabular}{|c|c|c|c|c|c|c|c|}
\hline 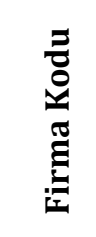 & 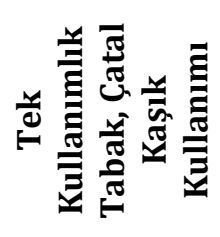 & 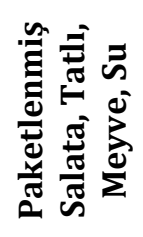 & 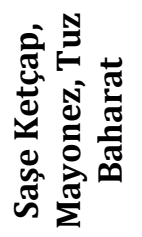 & 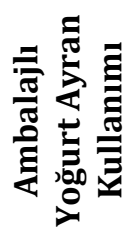 & 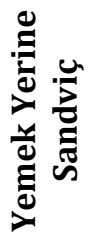 & 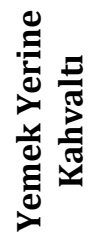 & 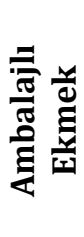 \\
\hline YF 1 & + & + & + & + & + & + & + \\
\hline YF 2 & + & + & + & + & + & + & + \\
\hline YF 3 & + & + & + & + & + & + & + \\
\hline YF 4 & + & + & + & + & + & + & + \\
\hline YF 5 & + & + & + & + & + & + & + \\
\hline YF 6 & + & + & + & + & + & + & + \\
\hline YF 7 & + & + & + & + & + & + & + \\
\hline YF 8 & + & + & + & + & + & + & + \\
\hline YF 9 & + & + & + & + & + & + & + \\
\hline YF 10 & + & + & + & + & + & + & + \\
\hline YF 11 & + & + & + & + & + & + & + \\
\hline YF 12 & + & + & + & + & + & + & + \\
\hline YF 13 & + & + & + & + & + & + & + \\
\hline YF 14 & + & + & + & + & + & + & + \\
\hline
\end{tabular}

\section{SONUÇ VE ÖNERILER}

Çin'in Wuhan kentinde başlayan ve hızla dünyayı etkisi altına alan covid-19 ile ilgili T.C. Sağlık Bakanlığı tarafından yapılan çalışmalar ve yayınlanan günlük raporlar Türk halkı tarafından endișeyle ve yakından takip edilmektedir. Yapmış olduğumuz çalışmaya göre Covid-19 salgınından yemek firmaları farklı sebeplerden yüksek oranda etkilenmiştir. Firmaların toplam kapasite kaybı \% 62.43'tür. Satış bütçesi oluşturulurken bu tahmin edilemeyen bir durum olarak görülmektedir. Yemek satışlarını etkileyen hususlar kontrol edilebilen ve edilemeyen diye ayrılmaktadır. Kontrol edilebilen durumlar arasında araç ve gereçlerin durumu, personelin iş görebilme yeteneği, işletmenin finansal durumu ve hedefleri bulunmaktadır. Kontrol edilemeyen durumlar ise deprem, terör, enflasyon, siyasal kargaşalar gibi unsurlardır (Boğan ve Sarışık, 2017). Dünyada ilk defa bu denli büyük çapta yaşanan ve şu an için henüz tedavi anlamında önlem alınamamış olan Covid-19 gibi salgın hastalıklar hazır yemek işletmeleri için yemek satışlarını etkileyen kontrol edilemeyen durumlar arasında yer almaktadır. Deprem, terör, enflasyon gibi kontrol edilemeyen durumların tahmini bir sonlanma süresi bulunmaktadır. Fakat daha önce yaşanmamış bir salgının ne zaman biteceği ve bittikten sonra hangi ekonomik sonuçların ortaya çıkacağı bilinmemektedir. Muhtemeldir ki salgının bitiminde dünya genelinde bir finansal kriz ve enflasyon yaşanacaktır. Bu da işletmeleri olumsuz anlamda etkileyecektir.

Covid-19 salgında firmaların faaliyet sürelerinin kapasiteleri üzerindeki etkilerine bakıldığında herhangi bir etkinin olmadığı göze çarpmaktadır. Faaliyet süresi 3 yll olan YF 3 ve 4 yıl olan YF 8 ve YF 9'un kapasite kayıp oranları sırasıyla \% 82, \% 48.53 ve \% 55.60 dır. Faaliyet süresi 26 yıl 
Koronavirüs (Covid-19) Salgınının Türkiye'deki Yemek Firmalarında Oluşturduğu Etkinin Belirlenmesi Üzerine Bir Araştırma

ve 44 yıl ile diğer firmalardan çok daha yüksek olan YF 4 ve YF 13 firmalarının kapasite kayıp oranları \%76.26 ve \%54.05 olmuştur. Bu durum yemek sektöründe uzun ylllar boyunca deneyimli olmanın daha önceden yaşanmamış kriz durumlarında bir etkisinin olmadığı sonucunu ortaya çlkartmaktadır.

Yemek firmalarının hizmet sunduğu kuruluşların yüksek sayılı olması kapasitenin o kuruluşlara kaymasına sebebiyet vermektedir. Söz konusu kuruluşta meydana gelen bir problem veya bu salgın gibi bir kriz anında alınan çalıșmama kararı yemek firmasını fazlaca etkilemektedir. Bu tarz salgın durumlarında düşük (5-120 kişi/gün) kapasiteli firmalar vardiyalı ve sosyal mesafeyi koruyarak çalıştıklarında kapasitelerinde daha az düşüş meydana gelmekte bu da yemek firmasının kapasite olarak riski dağıtmasına sebep olmaktadır.

Salgının bu şekilde devam etmesi, kısa sürede önlem alınamaması ve kapasite düşüşü yemek firmalarında personelin iş akdini feshetmeye varan durumların ortaya çıkmasına sebebiyet verebileceği düşünülmektedir. Çalışmamıza katılan yemek firmaları 06.04.2020 tarihine kadar personel çıkartmamışlardır. Mevcut personel yıllık izinlerini kullanmaktadır.

Covid-19'un yayılmasını önlemenin en önemli yolu temastır (Ovalı, 2020). Yemek firmalarının müşterileri almış oldukları önlemlerin tamamı mümkün olabilecek teması ortadan kaldırmaya yöneliktir. Yemek dağıtım tezgahında bulunan yoğurt, salata, ekmek gibi insanların virüs bulaştırabileceği gıda maddelerinin kişiye özel ambalajlarda sunulması yerinde bir karar olarak görülmektedir. Gıda maddelerinin haricinde yıkanarak tekrar kullanılan çatal, kaşı, bardak, tabak gibi ekipmanların etkin yıkama olamayabileceği veya yıkama sonrasında tekrar insanlardan virüs bulaştırabileceği riskine karşın tek kullanımlık, ambalajlı, ambalajını yemek yiyen kişinin açarak kullandığı ekipmanlar yemek firmaları tarafından kullanılmaktadır.

Hijyen eğitiminin hazır yemek işletmelerinin eğitim planlarında bulunması ve sürekli olarak belirli periyotlarda tekrarlanması gerekmektedir (Kaya ve İlhan, 2018). Virüsün yayılımı bir hijyen problemidir. Ellerin gıda güvenliği kurallarına uygun şekilde yıkanmaması, eldiven, maske ve dezenfektanın yemek firması çalışanları tarafından etkin kullanılmaması hastalığın yayılmasını hızlandıracaktır. Personelin çalışırken sosyal mesafe kurallarına uyması doğru ve yerinde uygulamalar olarak değerlendirilmektedir.

Yaptığımız çalışma sonucu elde ettiğimiz veriler ışığında önerilerimizi şu sıralamaktayız;

- Yemek firmalarının tarihsel süreci inceleyerek dünya üzerinde geçmişte meydana gelmiş problemlerin tekrar yaşanabileceğine ile alakalı kendilerine kriz senaryoları oluşturmaları ve bunun için bütçe oluşturmaları gerektiği kanaatindeyiz.

- Yemek firmalarının kapasite kaybı riskini dağıtmak amacıyla çok yüksek sayılı ve çok düşük sayılı müşterileri arasında dengeli bir portföy oluşturmaları gerektiği düşünülmektedir.

- Kapalı ambalajda yoğurt, ekmek, su, çatal, kaşık gibi gıda ve sarf malzemelerin maliyetlerinin müşteri ile paylaşılması gerektiği düşünülmektedir.

- Firmalar tarafından personel iş akdi feshedilmesi düşünülmemelidir.

- Günümüz yemek firmaları yemeği pişirmekte ve sıcak olarak müşteriye sevk etmektedirler. Bu üretim şeklinde bir depolama söz konusu olmamaktadır. Dolayısıyla yemek üretildikten sonra hemen tüketilmesi gerekmektedir. Endüstriyel yemekte kullanılan bir yemek üretim şekli de cook-chill adı verilen pişir ve soğut sistemidir. Cook - chill yönteminde yemek pişirilmekte, arzu edilen porsiyonlarda ambalajlanmakta ve soğukta $\left(0-2^{\circ} \mathrm{C}\right)$ muhafaza edilmektedir. Bu sistemde yemek sıcaklığı 90 dakikalık sürede $3^{\circ} \mathrm{C}$ 'nin altına indirilmektedir (Çopur ve Tamer, 2003: 162-164). Yemek firmalarının, üretim tesislerinde cook - chill yöntemiyle de yemek üretebilmeleri mümkündür. Bu amaçla tesise ilave soğutma ve 
depolama alanları yapmak yeterli olabilecektir. Günümüzde yaşanan salgın gibi durumlarda çalışanlar işyerlerine gitmediği için evde zaman geçirmektedirler. Uygun planlanmış bir dağıtım ağıyla yemek firmalarının, cook-chill yöntemiyle pişirecekleri ve depolayacakları yemekleri evlerinde kalan vatandaşlar için satışa sunabilecekleri ve bu krizden kurtulabilecekleri düşünülmektedir.

\section{KAYNAKLAR}

Acar, Y. (2020). Yeni Koronavirüs (Covid-19) Salgını ve Turizm Faaliyetlerine Etkisi. Güncel Turizm Araştırmaları Dergisi. 4(1):7-21.

Akpınar, F. ve Üstün, Y. ( 2020). Kadın hastalıkları ve doğum pratiğinde SARS-COV-2 (COVID-19) enfeksiyonu ile ilgili güncel bilgiler. Türk Kadın Sağlığı ve Neonatoloji Dergisi, 2 (1):13-16.

Boğan, E. ve Sarışıı, M. (2017). Yiyecek İçecek Satış Tahminleri. Yiyecek İçecek İşletmelerinde Maliyet Kontrolü, Ed. Mehmet Sarışık. Detay Yayıncılık, Ankara.

Çopur, U. ve Tamer, C.E. (2003). Modern Catering Sistemi Cook - Chill. Gıda 28 (2):159-167.

Demirel, S. (2009). Hazır Yemek Üretimi Yapan İşletmelerde Çalışanların Hijyen Bilgi Düzeylerinin Belirlenmesi. Yayımlanmamış Yüksek Lisans Tezi. Namık Kemal Üniversitesi Fen Bilimleri Enstitüsü, Tekirdağ.

Gürsoy D (1997).Yemek ve Yemekçiliğin Evrimi, Eren Yayınevi,114s, İstanbul.

Karcıoğlu, Ö. (2020). Coronavirüs Nedir, Nasıl Korunabiliriz? Anka Tıp Dergisi, 2 (1):66 - 71.

Neuman, W. L. (2012). Toplumsal Araştırma Yöntemleri: Nicel ve Nitel Yaklaşımlar I-II. Cilt (5. Basım). İstanbul: Yayın Odası.

Ovalı, F. (2020). Yenidoğanlarda COVID-19 Enfeksiyonları. Anadolu Kliniği Tıp Bilimleri Dergisi, 25 (özel sayı 1):25-35.

Sucu, N, Durmuş, S, Şen, M.A.(2020). Yemek sektörüne genel bakış. http://www.gidamo.org.tr.

Şen, M.A. (2017). Kritik kontrol noktalarında (KKN) risk matrisi uygulaması "bir restoran örneği". Akademik Sosyal Araştırmalar Dergisi, 5(61):214-227.

Şen, M. A., \& Şimşek, M., (2020). Toplu Yemek Tüketicilerinin Yemeğe Yönelik Genel Memnuniyet Düzeylerinin Belirlenmesi Üzerine Bir Çalışma. Gastroia: Journal of Gastronomy And Travel Research, $4(1), 121-135$.

URL 1, https://www.saglik.gov.tr/TR,64383/koronavirus-alacagimiz-tedbirlerden-guclu-degildir.html (Son Erişim Tarihi: 09.04.2020)

URL 2, https://www.aa.com.tr/tr/info/infografik/18039 , Kovid-19 Topluluk Hareketliliği (Son Erişim Tarihi: 06.04.2020)

URL 3, https://www.who.int/docs/default-source/coronaviruse/situation-reports/20200404-sitrep-75covid-19.pdf?sfvrsn=99251b2b_2 (Son Erişim Tarihi: 09.04.2020)

URL 4, https://www.saglik.gov.tr/ (Son Erişim Tarihi: 09.04.2020 )

URL 5, https://www.icisleri.gov.tr/ (Son Erişim Tarihi: 09.04.2020 ) 
Koronavirüs (Covid-19) Salgınının Türkiye'deki Yemek Firmalarında Oluşturduğu Etkinin Belirlenmesi Üzerine Bir Araștırma

Yalım Kaya, S. ve İlhan, S. (2018). Toplu Yemek (Hazır Yemek) Sektöründe Yaşanan Problemler ve Çözüm Önerileri. Güncel Turizm Araştırmaları Dergisi, 2(Ek.1):553-581.

Yıldırım, A., \& Şimşek, H. (2008). Sosyal Bilimlerde Nitel Araştırma Yöntemleri (6. Baskı). Ankara: Seçkin Yayıncılık. 